\title{
ANTIDIABETIC ACTIVITY OF CALOTROPIS GIGANTEA WHITE FLOWER EXTRACTS IN ALLOXAN INDUCED DIABETIC RATS
}

\author{
Manivannan R*, Shopna $\mathbf{R}$ \\ Department of Chemistry, Government Arts College (Autonomous), Kumbakonam, Tamilnadu-612001, India
}

\section{ABSTRACT}

Calotropis gigantea white (Asclepiadaceae) has been documented as a traditional treatment of diabetes. The aim of this study was to evaluate the antidiabetic activity of chloroform and ethyl acetate extracts from the flower in normal and alloxan-induced diabetic rats. Blood samples were obtained and blood glucose levels were analyzed employing a glucometer at different time intervals on 1 st, 4th, 8th and 12th day of the treatment with C. gigantea white extracts compare to glibenclamide (10 mg / kg). From the results, it is revealed that the test chloroform, and ethyl acetate extracts at a dose level $500 \mathrm{mg} / \mathrm{kg}$, showed a significant reduction in blood sugar level day in a progressive manner comparable to glibenclamide. Biochemical parameters, including hemoglobin, urea, creatinine, serum cholesterol, low-density lipoprotein (LDL), and high-density lipoprotein (HDL) were also assessed. Treatment of diabetic rats with the two extracts of this plant restored the elevated biochemical parameters significantly $(\mathrm{p}<0.05)$ to the normal level. It also proves the traditional claim with regard to C. gigantea white for its anti-diabetic activity.

Keywords: Calotropis gigantea white flowers, antidiabetic activity, alloxan, lipid profile.

Article Info: Received 20 April, 2017; Review Completed 05 May, 2017; Accepted 05 May, 2017; Available online May 15, 2017

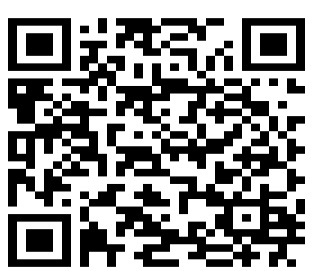

Cite this article as:

Manivannan R, Shopna R, Antidiabetic activity of Calotropis gigantea white flower extracts in alloxan induced diabetic rats, Journal of Drug Delivery and Therapeutics. 2017; 7(3):106-111

DOI: http://dx.doi.org/10.22270/jddt.v7i3.1447

*Address for Correspondence

Manivannan R, Department of Chemistry, Government Arts College (Autonomous), Kumbakonam, Tamilnadu-612001, India. E-mail address: manickam_mani@yahoo.co.in

\section{INTRODUCTION}

Diabetes is a chronic disorder in the metabolism of carbohydrates, proteins, and fat due to absolute or relative deficiency of insulin secretion with/without varying the degree of insulin resistance ${ }^{1}$. Effective blood glucose control is the key to preventing or reversing diabetic complications and improving the quality of life in patients with diabetes ${ }^{2}$. Diabetes also gives rise to various secondary problems such as cataracts, microvascular problems, and neuropathy. These secondary problems commonly arise due to oxidative stress and DNA damage caused in cells by means of free radical generation ${ }^{3}$. Management of diabetes without side effects is still challenging to the medical community. Pharmacological and clinical trials of medicinal plants have shown anti-diabetic effects and repair of $\beta$-cells of islets of Langerhans ${ }^{4}$. Many of these medicinal plants and herbs are a potential source of many drugs used in modern medicine, for example, quinine, opium alkaloids, atropine, cardiac glycosides (digitalis) and the popular hypoglycemic drug glucophage (metformin), derived from Galega officinalis $^{5}$. A wide range of plants has been reported in the literature to prevent and treat diabetes.

Calotropis gigantea white (Asclepiadaceae), commonly known as milkweed or swallow-worth, is found chiefly in temples and Wasteland throughout India ${ }^{6}$. The traditional healers suggested that, when using $\mathrm{C}$. gigantea for medication, white flowering should be preferred over purple flowering. It is known for various medicinal properties in the traditional medicinal system and uses to cure a variety of diseases. It has been 
reported as a traditional folkloric medicine for treatment of asthma in the Indian literature ${ }^{7}$. Phytochemical studies on Calotropis have afforded several types of compounds such as Cardenolide, triterpenoids, alkaloids, resins, anthocyanins and proteolytic enzymes in latex, flavonoids, tannins, sterol, saponins and cardiac glycosides. Flowers contain terpenes, multi fluorenol, and cyclisadol $^{8}$. Hence, taking into consideration the traditional evaluation and reported activities, the present study was undertaken to test plant $C$. gigantea white for its antidiabetic activities of the extract on alloxan induced rats as animal model and the effect of the carbohydrate metabolizing enzymes and lipid, as no work is done in this direction and to check possible role of plant in antidiabetic activity.

\section{MATERIALS AND METHODS}

\section{Collection and identification of plant material}

Calotropis gigantea white, flowers were collected in the month of February - March from the campus of Siva Temple, Thiruvisanallur, Thanjavur India and the plant was identified by Dr. N. Ramakrishnan, Associate Professor and Head, Department of Botany, Government Arts College (Autonomous), Bharathidasan University, Trichirappalli, Tamilnadu, India. A voucher specimen (GACBOT-107) was deposited in the research laboratory, Botany for future reference. The collected fresh flower materials were washed properly and dried in the shade. Dried plant material was subjected to reduction to coarse powdered and stored in airtight container for further use.

\section{Preparation of plant extract}

The flowers $(500 \mathrm{~g})$ of Calotropis gigantea white were extracted three times with $95 \%$ methanol (4 X $500 \mathrm{~mL})$ at room temperature $\left(30 \pm 2{ }^{\circ} \mathrm{C}\right)$. Following filtration, the combined methanol extract was evaporated to dryness under reduced pressure to give a crude extract. The crude methanol extract was suspended in hot water $(1000 \mathrm{~mL})$ and that was subjected to column chromatography over Silica gel using with chloroform and ethyl acetate, and the solvent recovered by simple distillation. Evaporation of the solvent under reduced pressure gave the crude extract $\mathrm{CHCl}_{3}(39.0 \mathrm{~g})$ and EtOAc (28.0 g) respectively. Each extract was dissolved in distilled water before its administration to the diabetic rats. This was prepared by dissolving $2 \mathrm{~g}$ of plant extract in $25 \mathrm{~mL} 2 \%$ Tween - 80 / distilled water and normal saline in a falcon tube in a hot water bath with vigorous shaking. The dose of each extract was calculated according to body weight before administration to the diabetic rats.

\section{Experimental animals}

Wistar albino rats (200-220 g) of either sex were used for this study and were kept in the animal house at $25 \pm$ $2{ }^{\circ} \mathrm{C}$ with relative humidity $50-55 \%$ along with light and dark cycles of $12 \mathrm{~h}$ respectively (6-10 h light, 18-6 h dark). The animals were fed with Standard animal feed (Hindustan Lever Ltd.) and water was applied ad libitum. The animal experiments were carried out in accordance with the guidelines of Committee for the Purpose of Care and Supervision of Experimental
Animals (CPCSEA) after approval from Institutional Animal Ethics Committee (IAEC), Bharathidasan University, Trichirappalli, Tamilnadu, India (Approval No. BDU/IAEC/2011/31/29.03.2011).

\section{Experimental design}

The animals were divided into six groups each containing six animals.

Group-I: Served as normal control. Control rats received only normal saline.

Group-II: The Second group of rats with diabetes was induced by intraperitoneal injection of alloxan for 2 days.

Group-III: Alloxan treated rats were administered the Glibenclamide $(10 \mathrm{mg} / \mathrm{kg}$ ) and served as standard.

Group-IV: Alloxan treated rats were administered the chloroform extract of Calotropis gigantea white (250 $\mathrm{mg} / \mathrm{kg}$ )

Group-V: Alloxan treated rats were administered the chloroform extract of Calotropis gigantea white (500 $\mathrm{mg} / \mathrm{kg}$ )

Group-VI: Alloxan treated rats were administered the ethyl acetate extract of Calotropis gigantea white (250mg / kg)

Group-VII: Alloxan treated rats were administered the ethyl acetate extract of Calotropis gigantea white (250mg / kg)

After the treatment period all the groups of rats were euthanized by anesthesia using chloroform vapor and the rats were sacrificed by decapitation. Then the blood was collected in a tube for analysis.

\section{Acute toxicity studies}

The resulting extracts were subjected to acute oral toxicity studies as per revised OECD Organization of Economic Co-operation and Development guidelines (OECD No. 425). The $C$. gigantea white flower extracts were devoid of any toxicity up to $2000 \mathrm{mg} / \mathrm{kg}$ body weight in albino rats $(200-220 \mathrm{~g})$ of either sex for a single oral dose monitored for 12 days. The optimum conditions for experiments were decided on the basis of pilot experiments carried out using three animals per group. For further experiments, a group of at least six animals was used for individual treatment. Based on exploratory studies, antidiabetic activity was investigated using the methanol, chloroform, and ethyl acetate extracts respectively. The control group received only the vehicle. The groups were observed mortality and behavioral changes during $48 \mathrm{~h}$.

\section{Evaluation of anti-diabetic activity}

Before starting the experiment, animals were separated according to their body weight. The animals were injected intraperitoneally with freshly prepared alloxan monohydrate at a concentration of $100 \mathrm{mg} / \mathrm{kg}$ in normal saline solution $(0.9 \mathrm{w} / \mathrm{v} \% \mathrm{NaCl})$, appears to be the easiest, most reliable practical method of inducing diabetes mellitus. A volume equivalent to $1 \mathrm{ml}$ of the stock solution was given intraperitoneally after which 
the blood glucose levels were measured at regular intervals (i.e., every $6 \mathrm{~h}$ ) four times daily for three days using digital display glucometer (One touch - Johnson \& Johnson Ltd.). Alloxan administration resulted in significant elevation of glucose level and reduction in body weight. Diabetes was confirmed by the elevated blood glucose levels determined at $72 \mathrm{~h}$. Initial blood sample was taken before the oral administration of the standard drug glibenclamide, test extracts at a dose of $300 \mathrm{mg} / \mathrm{kg}$ of $C$. gigantea white. The blood glucose level test was done on the normal, diabetic, and treated diabetic rats were measured at $0,4,8$ and 12 days after oral administration of glibenclamide and plant extracts.

\section{Biochemical analysis}

After blood glucose estimation on day 12, whole blood samples were drawn from the tail vein during the course of the experiment. At the end of the experimental period (12 days), the rats were anesthetized with chloroform following a 12 - hour fast. Blood samples were drawn by cardiac puncture into plain tubes. The blood samples were centrifuged at $3500 \mathrm{rpm}$ for 20 minutes using a refrigerated centrifuge at $4^{\circ} \mathrm{C}$ (Remi Laboratory Instruments, Mumbai, India). The serum collected was stored at $-20^{\circ} \mathrm{C}$ until needed. Serum albumin was determined using the bromocresol (BCG) green method with an Autopak kit. The total protein present in serum was estimated by the Biuret method ${ }^{9}$ using an Autopak kit. Serum was separated and analyzed for serum cholesterol, ${ }^{10}$ serum HDL, ${ }^{11}$ serum LDL, ${ }^{12}$ serum creatinine, ${ }^{13}$ serum urea, ${ }^{14}$ levels of hemoglobin using the ion exchange resin method ${ }^{15}$ with kits purchased from Diotek India Ltd, Mumbai, India, were estimated. To the animals, standard drug glibenclamide tablets (10 $\mathrm{mg} / \mathrm{kg}$ orally) and the test extracts $(250 \& 500 \mathrm{mg} / \mathrm{kg}$ orally) were administered by dissolving in $2 \%$ Tween $80 /$ distilled water and normal saline respectively.

\section{Statistical analysis}

All the values of body weight, fasting blood sugar, and biochemical estimations were expressed as mean \pm standard error of mean (SEM) and analyzed for ANOVA and post hoc Dunnet's $t$-test. Differences between groups were considered significant at $P<0.05$ levels.

\section{RESULTS AND DISCUSSION}

\section{Alloxan induced anti diabetic activity}

The anti-diabetic effect of the test extracts on the blood glucose levels of diabetic rats is shown in Table 1 . The effect seems to reach the maximum after the $12^{\text {th }}$ day of treatment and remains constant. Glibenclamide used as standard drug exhibited the highest activity with a final decrease of $87.26 \pm 2.68 \mathrm{mg}$ on day 12 , followed by ethyl acetate extract at dose of $250 \& 500 \mathrm{mg} / \mathrm{kg}$ $(124.41 \pm 2.56$ and $104.41 \pm 2.69 \mathrm{mg})$ and chloroform extract at a dose of $250 \& 500 \mathrm{mg} / \mathrm{kg}(131.25 \pm 2.64$ and $109.25 \pm 2.67 \mathrm{mg}$ ) respectively. There is no significant change in the blood glucose levels of rats in group I that received normal saline solutions (negative control). Table 2 showed the body weight changes in the normal and experimental animals in each group. The mean body weight of the animals after 12 days of treatment with chloroform and ethyl acetate extract (500 $\mathrm{mg} / \mathrm{kg})$ and glibenclamide $(10 \mathrm{mg} / \mathrm{kg})$ was $179.29 \pm$ $4.38, \quad 186.82 \pm 4.34$, and $198.32 \pm 4.33 \mathrm{mg} / \mathrm{kg}$ respectively.

Table 1: Effect of extracts from Calotropis gigantea white on fasting blood glucose level in alloxan induced diabetic rats

\begin{tabular}{|l|l|l|l|l|l|}
\hline \multirow{2}{*}{ Group } & \multirow{2}{*}{ Treatment } & \multicolumn{4}{c|}{ Fasting blood glucose level $(\mathrm{mg} / \mathrm{dI})$} \\
\cline { 3 - 6 } & & \multicolumn{1}{c|}{ Initial } & $\mathbf{4}^{\text {th }}$ day & $\mathbf{8}^{\text {th }}$ day & $\mathbf{1 2}^{\text {th }}$ day \\
\hline I & Normal Control & $85.42 \pm 2.64$ & $86.83 \pm 1.12$ & $84.00 \pm 1.16$ & $85.68 \pm 1.40$ \\
\hline II & Diabetic Control & $195.72 \pm 4.24$ & $214.12 \pm 4.26$ & $236.22 \pm 2.39$ & $258.16 \pm 2.52$ \\
\hline III & Glibenclamide $10 \mathrm{mg} / \mathrm{kg})$ & $196.36 \pm 2.52$ & $158.16 \pm 2.43$ & $125.26 \pm 2.81$ & $87.26 \pm 2.68$ \\
\hline IV & Chloroform extract $(250 \mathrm{mg} / \mathrm{kg})$ & $198.57 \pm 2.83$ & $174.45 \pm 2.47$ & $158.84 \pm 2.37$ & $131.25 \pm 2.64$ \\
\hline V & Chloroform extract $(500 \mathrm{mg} / \mathrm{kg})$ & $198.57 \pm 2.83$ & $167.45 \pm 2.47$ & $145.54 \pm 2.37$ & $109.25 \pm 2.67$ \\
\hline VI & Ethyl acetate extract $(250 \mathrm{mg} / \mathrm{kg})$ & $194.62 \pm 2.66$ & $168.36 \pm 2.29$ & $149.27 \pm 2.62$ & $124.41 \pm 2.56$ \\
\hline VII & Ethyl acetate extract $(300 \mathrm{mg} / \mathrm{kg})$ & $196.39 \pm 2.56$ & $159.25 \pm 3.45$ & $137.26 \pm 3.56$ & $101.41 \pm 2.69$ \\
\hline
\end{tabular}

Values are expressed in Mean $\pm \mathrm{SD}\left(\mathrm{n}={ }_{6}\right) . \quad$ There is no significant difference between standard and test drug at $\mathrm{P}<0.05$ significant level.

Table 2: Effect of extracts from Calotropis gigantea white on body weight in alloxan induced diabetic rats

\begin{tabular}{|l|l|c|c|c|c|}
\hline \multirow{2}{*}{ Group } & \multicolumn{1}{|c|}{ Treatment } & \multicolumn{4}{|c|}{ Body weight of the animal $(\mathrm{g})$} \\
\cline { 3 - 6 } & & Initial & $\mathbf{4}^{\text {th }}$ day & $\mathbf{8}^{\text {th }}$ day & $\mathbf{1 2}^{\text {th }}$ day \\
\hline I & Normal Control & $212.67 \pm 1.33$ & $207.33 \pm 4.52$ & $210.28 \pm 2.13$ & $211.17 \pm 3.15$ \\
\hline II & Diabetic Control & $203.22 \pm 1.32$ & $192.67 \pm 2.84$ & $167.43 \pm 2.36$ & $121.33 \pm 3.16$ \\
\hline III & Glibenclamide $(10 \mathrm{mg} / \mathrm{kg})$ & $218.42 \pm 2.44$ & $207.46 \pm 4.38$ & $204.29 \pm 3.44$ & $198.32 \pm 4.33$ \\
\hline IV & Chloroform extract $(250 \mathrm{mg} / \mathrm{kg})$ & $219.36 \pm 1.67$ & $194.30 \pm 4.24$ & $172.38 \pm 3.26$ & $165.17 \pm 4.36$ \\
\hline V & Chloroform extract $(500 \mathrm{mg} / \mathrm{kg})$ & $216.98 \pm 2.41$ & $209.61 \pm 4.34$ & $186.48 \pm 3.42$ & $179.29 \pm 4.38$ \\
\hline VI & Ethyl acetate extract $(250 \mathrm{mg} / \mathrm{kg})$ & $217.37 \pm 2.29$ & $199.33 \pm 4.26$ & $178.63 \pm 3.32$ & $168.82 \pm 4.39$ \\
\hline VI & Ethyl acetate extract $(500 \mathrm{mg} / \mathrm{kg})$ & $217.37 \pm 2.29$ & $199.33 \pm 4.28$ & $188.63 \pm 3.42$ & $186.82 \pm 4.34$ \\
\hline
\end{tabular}

Values are expressed in Mean $\pm \mathrm{SD}(\mathrm{n}=6)$. There is no significant difference between standard and test drug at $\mathrm{P}<0.05$ significant level. 
Table 3: Effect of extracts from Calotropis gigantea white on $12^{\text {th }}$ day on biochemical parameters in alloxan induced diabetic rats $(\mathrm{mg} / \mathrm{dI})$

\begin{tabular}{|c|c|c|c|c|c|}
\hline Groups & Treatments & \multicolumn{3}{|c|}{ Biochemical parameter } \\
\cline { 3 - 6 } & & Hemoglobin & Albumin & Serum Urea & $\begin{array}{c}\text { Serum } \\
\text { Creatinine }\end{array}$ \\
\hline I & Normal Control & $13.25 \pm 0.32$ & $3.64 \pm 0.17$ & $25.52 \pm 1.2$ & $0.64 \pm 0.2$ \\
\hline II & Diabetic Control & $9.56 \pm 0.47$ & $2.47 \pm 0.15$ & $56.43 \pm 1.7$ & $0.98 \pm 0.5$ \\
\hline III & Glibenclamide $(10 \mathrm{mg} / \mathrm{kg})$ & $12.91 \pm 0.48$ & $3.82 \pm 0.14$ & $32.14 \pm 2.4$ & $0.56 \pm 0.2$ \\
\hline IV & Chloroform extract $(250 \mathrm{mg} / \mathrm{kg})$ & $11.12 \pm 0.42$ & $3.72 \pm 0.15$ & $43.32 \pm 2.1$ & $0.73 \pm 0.4$ \\
\hline V & Chloroform extract $(500 \mathrm{mg} / \mathrm{kg})$ & $12.26 \pm 0.46$ & $3.55 \pm 0.17$ & $38.32 \pm 2.3$ & $0.62 \pm 0.4$ \\
\hline VI & Ethyl acetate extract $(250 \mathrm{mg} / \mathrm{kg})$ & $11.39 \pm 0.44$ & $3.49 \pm 0.14$ & $41.21 \pm 1.8$ & $0.78 \pm 0.5$ \\
\hline VII & Ethyl acetate extract $(500 \mathrm{mg} / \mathrm{kg})$ & $12.69 \pm 0.48$ & $3.78 \pm 0.16$ & $34.41 \pm 2.2$ & $0.58 \pm 0.2$ \\
\hline
\end{tabular}

Values are expressed in Mean \pm SD $(n=6)$. There is no significant difference between standard and test drug at $\mathrm{P}<0.05$ significant level.

Table 4: Effect of extracts from Calotropis gigantea white on $12^{\text {th }}$ day on biochemical parameters in alloxan induced diabetic rats $(\mathrm{mg} / \mathrm{dI})$

\begin{tabular}{|c|l|c|c|c|c|}
\hline \multirow{2}{*}{ Groups } & \multicolumn{2}{|c|}{ Treatments } & \multicolumn{4}{c|}{ Biochemical parameter } \\
\cline { 3 - 6 } & & $\begin{array}{c}\text { Serum } \\
\text { Protein }\end{array}$ & $\begin{array}{c}\text { Serum } \\
\text { Cholesterol }\end{array}$ & Serum HDL & Serum LDL \\
\hline I & Normal Control & $7.38 \pm 0.45$ & $158.12 \pm 3.5$ & $38.22 \pm 1.7$ & $84.33 \pm 3.4$ \\
\hline II & Diabetic Control & $4.36 \pm 0.23$ & $247.23 \pm 5.2$ & $28.38 \pm 1.5$ & $187.49 \pm 6.8$ \\
\hline III & Glibenclamide $(10 \mathrm{mg} / \mathrm{kg})$ & $6.98 \pm 0.84$ & $138.46 \pm 4.2$ & $48.43 \pm 1.7$ & $69.62 \pm 4.4$ \\
\hline IV & Chloroform extract $(250 \mathrm{mg} / \mathrm{kg})$ & $6.45 \pm 0.82$ & $165.24 \pm 5.2$ & $30.32 \pm 1.5$ & $115.10 \pm 5.2$ \\
\hline V & Chloroform extract $(500 \mathrm{mg} / \mathrm{kg})$ & $6.84 \pm 0.84$ & $149.23 \pm 4.4$ & $36.10 \pm 1.8$ & $78.70 \pm 4.5$ \\
\hline VI & Ethyl acetate extract $(250 \mathrm{mg} / \mathrm{kg})$ & $6.38 \pm 0.82$ & $162.24 \pm 5.8$ & $33.63 \pm 1.4$ & $109.45 \pm 5.1$ \\
\hline VII & Ethyl acetate extract $(500 \mathrm{mg} / \mathrm{kg})$ & $6.89 \pm 0.85$ & $144.12 \pm 4.3$ & $44.28 \pm 1.8$ & $73.70 \pm 4.6$ \\
\hline
\end{tabular}

Values are expressed in Mean \pm SD $(n=6)$. There is no significant difference between standard and test drug at $\mathrm{P}<0.05$ significant level.

\section{Biochemical analysis}

The biochemical parameters (Table $3 \& 4$ ) such as serum cholesterol, serum LDL, serum urea and serum creatinine levels were significantly decreased and HDL levels were increased by test various extracts of $C$. gigantea white and glibenclamide. The results also showed the levels of hemoglobin in control and experimental groups of rats. A significant decrease in the level of hemoglobin was observed in diabetic rats $(9.56 \pm 0.47)$ when compared to control rats. After treatment with glibenclamide $(10 \mathrm{mg} / \mathrm{kg})$ and chloroform and ethyl acetate extracts of $C$. gigantea white $(250 \& 500 \mathrm{mg} / \mathrm{kg})$ to diabetic rats resulted $(12.91$ \pm 0.48 and $12.26 \pm 0.46,12.69 \pm 0.48 \mathrm{mg})$ in the restoration of hemoglobin level to near normal $(P<0.05)$. Serum urea and serum creatinine levels were decreased significantly $(\mathrm{p}<0.05)$ after the treatment with $500 \mathrm{mg}$ of chloroform, ethyl acetate extracts and glibenclamide (urea: $38.32 \pm 2.3 ; 34.41 \pm 2.2$; and $32.14 \pm 2.4 \mathrm{mg}$; creatinine: $0.62 \pm 0.4 ; 0.58 \pm 0.2 ;$ and $0.56 \pm 0.2 \mathrm{mg}$ ) and the activity was comparable with that of the standard drug glibenclamide (urea: $32.14 \pm 2.4$; creatinine: $0.56 \pm 0.2 \mathrm{mg}$ ) respectively.

The present investigation showed the level of lipids in normal and tested animals. Administration of the chloroform and ethyl acetate extracts of the flowers of C. gigantea to alloxan monohydrate -diabetic rats protected the alterations of lipid levels. There was a significant increase in total protein content in the treated diabetic rats compared with the diabetic controls. The mean total protein content in rats treated with the test chloroform and ethyl acetate extract at a dose of 500 $\mathrm{mg} / \mathrm{kg}$ was $6.84 \pm 0.84,6.89 \pm 0.85$ respectively, which were slightly lower than that the total protein content in rats treated with the glibenclamide at dose of $10 \mathrm{mg} / \mathrm{kg}$ $(6.98 \pm 0.84 \mathrm{mg})$. There was a significant decrease in the levels of total cholesterol $(149.23 \pm 4.4 ; 144.12 \pm 4.3$ $\mathrm{mg}$ ) and significant increase in the level of HDLcholesterol $(36.10 \pm 1.8 ; 44.28 \pm 1.8 \mathrm{mg})$ and LDLcholesterol $(78.70 \pm 4.5 ; 73.70 \pm 4.6 \mathrm{mg})$ respectively and the activity was comparable with that of the standard drug, glibenclamide (total cholesterol: $138.46 \pm$ $4.2 \mathrm{mg}$; HDL; $48.43 \pm 1.7 \mathrm{mg}$; LDL: $69.62 \pm 4.4 \mathrm{mg}$ ).

From the results, it is revealed that the test chloroform, and ethyl acetate extracts at a dose level 250 \& $500 \mathrm{mg} /$ $\mathrm{kg}$, showed a significant reduction in blood sugar level day in a progressive manner comparable to glibenclamide. The treatment of diabetes with phytomedicine proved much safer than synthetic drugs throughout the world and gained importance in recent years $^{16}$. The mean body weight of the diabetic rats decreased significantly $(P<0.05)$ compared to diabetic treated rats. The administration of a various extract of $C$. gigantea white restored these levels significantly towards normal. This may also be due to the protective effect of the extracts in controlling muscle wasting i.e. reversal of gluconeogenesis. Due to insulin deficiency 
protein content is decreased in muscular tissue by proteolysis ${ }^{17}$. Alloxan caused body weight reduction, which is reversed by chloroform and ethyl acetate extract at high dose $(500 \mathrm{mg} / \mathrm{kg})$ is more effectively than at low dose $(250 \mathrm{mg} / \mathrm{kg})$ after 12 days of treatment.

Biochemical parameters indicate that flower extracts of this plant had favorable effects on lipid metabolism of diabetic rats. An increase in the level of hemoglobin in the diabetic control group of rats is due to the presence of a large amount of blood glucose which reacts with hemoglobin to form glycosylated hemoglobin ${ }^{18}$. Administration of alloxan decreases serum albumin levels due to increased non-enzymatic glycosylation of protein $^{19}$. Treatment of diabetic rats with chloroform and ethyl acetate extracts restored albumin to normal levels. On administering at 250 and $500 \mathrm{mg} / \mathrm{kg}$ various test extracts from $C$. gigantea white orally to diabetic rats decreased serum urea and creatinine, more effectively, and could be explained by the regenerative ability of the renal function. Diabetic produces the elevation of urea and creatinine which are considered to be significant markers of renal dysfunction ${ }^{20}$. The diabetic effect of plant extracts was similar to that of glibenclamide and appears to be through inhibition of gluconeogenesis since serum urea was reduced and skeletal muscle mass was increased. The elevated level of serum cholesterol, LDL, and reduced level of HDL possess to be rise of a factor for developing microvascular complication leading atherosclerosis and cardiovascular diseases like coronary heart disease ${ }^{21}$.

The results of the present study are also supported by the earlier reports on the hypoglycemic activity of $C$. gigantea leaves and flowers (purple color) extract ${ }^{22}$, against alloxan induced diabetes mellitus. In this study, the maximum activity was found in chloroform and ethyl acetate extracts of $C$. gigantea white flowers have been reported to contain 4-methoxy-3-(methoxymethyl) phenol and 4-methoxy-N2-(5-bromo-2-methoxy benzylideno) benzhydrazide is the major compounds in the both extracts from GC-MS spectrum reported previously ${ }^{23}$. Phenolic compounds were considered as

\section{REFERENCES}

1. Jarald E, Joshi SB, Jain DC. "Diabetes and Herbal Medicines", Iran. J. Pharmaco Therapeut., 2008; 7(1): 97106.

2. DeFronzo RA. "Pharmacologic therapy for type 2 diabetes mellitus", Ann. Intern. Med., 1999; 131: 281-303.

3. Wolff SP. "Diabetes mellitus and free radicals. Free radicals, transition metals and oxidative stress in the aetiology of diabetes mellitus and complications", British Med. Bull., 1993; 49: 642- 652 .

4. Ahmed ABA, Rao AS, Rao MV. "In vitro callus and in vivo leaf extract of Gymnema sylvestre stimulate $\beta$-cells regeneration and anti-diabetic activity in Wistar rats", Phytomedicine, 2010; 17: 1033-1039.

5. Grover JK, Yadav S, Vats V. "Medicinal plants of India with anti-diabetic potential", J. of Ethanopharmacol., 2002; 81: 81-100.

6. Singh U, Wadhwani AM, Johri BM. "Dictionary of economic plants of India", In: Jaiswal PL, editor. Indian Council of Agricultural Research New Delhi, 1996; 83:38-39.

7. Varier PS. "Indian Medicinal Plants", Orient Longman Pvt. Ltd New Delhi, 2003; 1: 341-43. the main contributors responsible for the free radical scavenging activity) of the total hexane extract of many plants $^{24}$ attributed the anti-diabetic, anti-inflammatory anti-tumor and anti-proliferative effect of many Labiatae species. Alkaloids, glycosides, carbohydrate, bitter principles, and saponins have similarly been implicated in the antidiabetic activities of a plant ${ }^{25}$. Alloxan destroys insulin-producing pancreatic B-cells through the formation of reactive oxygen species that cause tissue damage ${ }^{26}$. However, it seems reasonable to suggest that the antioxidant and radical scavenging effects of this plant ${ }^{23}$ may play a key role in protecting pancreatic tissues from oxidants including that generated by alloxan. However, the presence of these compounds in $C$. gigantea extracts could be mediated, at least in part, through activation of these natural products in the in the diabetes treatment have decreased blood glucose levels of diabetic rat and protected the alterations of lipid levels.

\section{CONCLUSION}

Our study clearly showed that Calotropis gigantea white caused marked hypoglycemic activity in alloxaninduced diabetic rat model which indicates antidiabetic potentials of the chloroform and ethyl acetate; extracts have beneficial effects on blood glucose levels. Our results support overall in vivo antidiabetic activity of the extracts that may prove to be of clinical importance in improving the management of diabetes. In addition, biochemical investigations have clearly elucidated the mechanism of action and will be helpful this plant extracts as a therapeutic target in diabetes research and the establishment of the exact mechanism(s) of action. The toxic effects and pharmacological activities of these plants should also be elucidated.

\section{Conflict of interest}

Authors declare that there is no conflict of interest to reveal.

8. Al-Yahiya MA, Al-Meshal IA, Mossa JS, Al-Badr AA and Tarig M. "Saudi plants: A phytochemical and biological approach Riyadh”, King Saud university press, 1990; 31- 34.

9. Fawcett JK, Scott JE. "A rapid and precise method for the determination of urea", J. Clin. Pathol., 1960; 13:156-159,

10. Roeschlau P, Bernt E, Gruber W. "Enzymatic determination of total cholesterol in serum", Zeitschrift fur Klinische Chemie und Klinische Biochemie, 1974; 12: 226.

11. Allain CC, Poon LS, Chan CS, Richmond W, Fu PC. "Enzymatic determination of total serum cholesterol", Clin. Chem., 1974; 20: 470 - 475 .

12. Friedewald WT, Levy RI, Fredrickson DS. "Estimation of the concentration of low-density lipoprotein cholesterol in plasma, without use of the preparative ultracentrifuge", Clin. Chem., 1972; 18: 499-502.

13. Bowers LD. "Kinetic serum creatinine assays I. The role of various factors in determining specificity", Clin. Chem., 1980; 26: 551-554.

14. Wilson BW. "Automatic estimation of urea using urease and alkaline phenol”, Clin. Chem., 1966; 12: 360-368. 
15. Trinder P. "Determination of glucose using glucose oxidase with an alternative oxygen acceptor", Ann. Clin. Biochem., 1969; 6: 24-27.

16. Kavishankar GB, Lakshmidevi N, Mahadeva Murthy S, Prakash HS, Niranjana SR. "Diabetes and medicinal plants-A review”, Int. J. Pharm. Biomed. Sci., 2011; 2(3): 65-80.

17. Swanston-Flat SK, Day C, Bailey CJ, Flatt PR. "Traditional plant treatments for diabetes: studies in normal and streptozotocin diabetic mice", Diabetologia, 1990; 33:462464.

18. Chattopadhyay RR. "Possible mechanism of antihyperglycemic effect of Azadirachta indica leaf extracts", J. Ethanopharmacol., 1999; 67: 373-376.

19. Lowry OH, Rosebrough NJ, Farr AL, Randall RJ. "Protein measurement with the Folin phenol reagent", J. of Biol. Chem., 1951; 193: 265-275.

20. Alarcon AFJ, Calzada BF, Hernandez GE, Ruiz AC. "Acute and chronic hypoglycemic effect of Ibervillea sonarae root extracts - II", J. Ethnopharmacol., 2005; 97: 447- 452.

21. Singh NS, Geetha M, Amudha P, Chakraborty A. "Evaluation of anti- diabetic activity of methanol extract of
Flacourtia jangomas (Lour) in streptozotocin induced diabetic rats". Int. J. Pharm. Bio. Sci., 2010; 1(3):1-11.

22. Nanu R Rathod, Havagiray R Chitme, Raghuveer I, Ramesh C. "Hypoglycemic Effect of Calotropis gigantea Linn. Leaves and Flowers in Streptozotocin-Induced Diabetic Rats”, Oman Medical Journal, 2011; 26(2): 104 -108.

23. Shopna $\mathrm{R}$, Prabakaran $\mathrm{K}$, Ilayaraja $\mathrm{S}$ Manivannan $\mathrm{R}$ "Antioxidant, Antimicrobial activities and GC-MS analysis of Calotropis gigantea white flowers", J. of Phytopharma., 2014; 3(6): 405-409.

24. Bakirel T, Bakirel U, Keleş OU, Ulgen SG, Yardibi H. "In vivo assessment of antidiabetic and antioxidant activities of rosemary (Rosmarinus officinalis) in alloxan-diabetic rabbits", J. Ethnopharmacol., 2008; 116: 64-73.

25. Reher. G., Slijepcevic M, Krans L. "Hypoglycemic activity of triterpenes and tannins from Sarcopterium spinosum and two sanguisorba species", Planta Med., 1991; 57:57-58.

26. Lee JH, Park JW, Kim JS, Park BH, Rho HW. "Protective Effect of Amomi Semen Extract on Alloxan-induced pancreatic B-Cell Damage", Phytotherapy. Res., 2008; 22: 86-90. 